\title{
9 From Liberalism to Underdevelopment
}

\author{
The Yugoslav elites facing Western \\ European economic integration in the \\ "long 1970s"
}

\section{Benedetto Zaccaria}

During the 1970s, Yugoslavia's stance towards the process of Western European economic integration, and the EEC (European Economic Community) in particular, was affected by the country's sui generis internal and international stance. Despite retaining a one-party communist political regime, the Yugoslav federation distinguished itself from the Soviet bloc countries by virtue of its autonomous course grounded on a self-management system ${ }^{1}$ and a non-aligned foreign policy. ${ }^{2}$ However, Yugoslavia was not immune from the political dynamics of the Soviet bloc due to the unresolved relationship with Moscow after the TitoStalin split (1948) ${ }^{3}$ and solid economic ties with the CMEA (Council of Mutual Economic Assistance). At the same time, Yugoslavia nurtured a realistic attitude towards the EEC. Unlike the Soviet bloc countries, which regarded the Common Market as an imperialist enterprise, Belgrade established direct diplomatic relations with the Community in 1968. These would lead to the conclusion of two trade agreements (in 1970 and 1973) and a cooperation agreement in $1980 .{ }^{4}$ During the decade under consideration, Yugoslavia was therefore at the edge of European regional economic integration processes. This specificity was further complicated by its internal configuration. Yugoslavia's status as a federal union of six republics (Slovenia, Croatia, Bosnia and Herzegovina, Serbia, Montenegro and Macedonia) and two autonomous provinces (Vojvodina and Kosovo) with different levels of economic development and dynamics of regional integration with the Common Market area resulted in a gradual process of decentralisation of political and economic competences, which was sanctioned by the adoption of a confederal constitution in 1974.

The aim of this chapter is to address the Yugoslav elites' views and predicaments regarding economic integration in Western Europe against this multi-faceted background. Overall, scholarly works on Yugoslavia's internal and international dynamics have largely neglected the Western European integration question. Famously, historians have focused on the country's early opening to the West in the immediate aftermath of the Tito-Stalin split ${ }^{5}$ and the successive deterioration of relations with the USSR and the Soviet bloc countries. ${ }^{6}$ Historical analysis has also broadly focused on the 1950s, when the self-management system, based on the social ownership of the means of production, was first introduced, 
and in parallel with this the country's economy started its early integration with the international economic system. ${ }^{7}$ As is highlighted in recent literature, during the early 1960s the Yugoslav political leadership was divided between conservatives and so-called liberals, who pushed for Yugoslavia's further integration in the world market and a closer relationship with its Western European partners. ${ }^{8}$ The eventual adoption of economic reforms in 1965 meant a success of the party's liberal reformers and resulted in a consequent acceleration of economic ties with the West. ${ }^{9}$ While literature on Yugoslavia during the 1960s has broadly illustrated the rationale and internal debates leading to this reform process, the effects of the process in the following decade are still to be systematically explored. ${ }^{10}$ Several reports and studies on Yugoslavia and the EEC, quoted in this study, were published in the 1970s, 1980s and 1990s. However, they were not based on archival research and did not dig into the internal debates on how to deal with the European integration question, which is what makes this study new. Archive-based studies focusing on EEC-Yugoslav relations during the 1970s have mainly focused on the EEC's viewpoint. ${ }^{11}$ The few historical accounts of Yugoslavia's stance in the international economy of the 1970s have addressed the federation's early relations with international financial institutions such as the International Monetary Fund (IMF) and World Bank and the rising dependence of the country on Western credits leading up to the debt-service crisis of $1982 .{ }^{12}$ In general, agreement exists among historians that relations with the West were crucial in the evolution of Yugoslavia's internal and external balance during the decade under consideration: the unresolved questions of the trade deficit and international debt after the energy crises of 1973 and 1979 were to affect the stability of the federation and the political leadership of the League of Communists of Yugoslavia (Savez Komunista Jugoslavije [SKJ], or the League). ${ }^{13}$

However the West, towards which Yugoslavia leaned during the 1970s, has been only vaguely addressed. It has sometimes been considered to be the international financial institutions ${ }^{14}$ or Yugoslavia's main Western partners, namely the US, ${ }^{15}$ West Germany, ${ }^{16}$ and Italy. ${ }^{17}$ But the picture of Yugoslavia's stance within the international political economy of the 1970s is still blurred and vague. While limited attention has been devoted to its relationship with the Organisation for European Economic Co-operation (OEEC) ${ }^{18}$ and the Council of Europe, ${ }^{19}$ the historical understanding of Belgrade's relations with its Western partners suffers from an overall neglect of its relationship with the EEC, which during the 1970s accounted for more than $40 \%$ of the country's foreign trade. Common Market countries were also the principal recipients of the Yugoslav migrant force and the main source of workers' remittances and foreign tourism. ${ }^{20}$ Finally, the EEC has only been considered within the context of the disintegration of the Yugoslav federation in the early 1990s, as if Yugoslavia had only passively dealt with the European integration question in previous years. ${ }^{21}$

This chapter re-assesses the political and economic rationale for Yugoslavia's relations with the EEC during the long 1970s, illustrating the internal debates among the country's elite at all levels (political, economic, academic) on the European integration question and the question's importance for the country's internal 
and external developments. The chapter's argument is that internal debates on the EEC were profoundly shaped by the internal evolution of the Yugoslav federation during the 1970s. The marked process of confederalisation that was initiated after the adoption of the 1974 constitution resulted in diverging economic interests between the individual republics and autonomous provinces. Internal contradictions within the federation, amplified by the centrifugal tendencies of the northern republics of Slovenia and Croatia, affected the elaboration of a comprehensive federal strategy towards the Community. This chapter illustrates the divergence between a political-diplomatic interpretation of the EEC by the federal centre (in particular the SKJ and the Federal Secretariat for Foreign Affairs) and an economic view of the Common Market as a source of hard currency, industrial technology and know-how, particularly among the republican leaderships. This divergence developed against a background of international economic recession and energy crises (1973 and 1979), which exposed the Yugoslav federation to unrestrained external borrowing and to the rise of a balance of trade deficit. The chapter considers how elite debates and inter-republican confrontation - a direct consequence of the 1974 reform - developed at the federal level. The internal policymaking of each individual republic and autonomous province is beyond the scope of this study. ${ }^{22}$

This work is structured in three chronological sections. The first explores Yugoslavia's internal debates on the EEC from the establishment of diplomatic relations between the parties (1968) to the signing of the first trade agreement in 1970. The second section addresses Yugoslav views of the EEC against the background of a rapidly evolving internal framework, characterised by the end of the liberal reforms launched in the mid-1960s and the adoption of the 1974 constitution. In this section, the economic consequences of the 1973 oil shock and the suspension of the trade provisions in Yugoslavia's agreement with the EEC are considered. Finally, the chapter focuses on the period 1975-80, addressing the deterioration in the balance of trade, centrifugal economic tendencies, the rise in foreign borrowing and the internal debates over the economic orientation of the country. In conclusion, this chapter depicts a declining trajectory from the enthusiastic prospects of an 'industrial' future in the 1960s to the disillusion of the late 1970s, when the country's elites focused on the 'underdevelopment question' to cover both the shortcomings of the self-management system and the centrifugal tendencies at the federal level.

A terminological disclaimer is needed. In this chapter, the 'republican' affiliations of the leading actors involved in internal debates on the EEC are highlighted. This is not to offer a post-1989 reading of the political dynamics of socialist Yugoslavia. The author is aware that the disintegration of the federation was the outcome of complex internal and international dynamics which will not be dealt with here. He is also aware that republican leanings were in most cases blended with ideological adhesion to the 'brotherhood and unity' principle - which the SKJ had espoused since 1945 to overcome the troubled legacy of the 'first' Yugoslavia (1918-41) and World War II - and that labels when applied to human beings by their nature offer a simplified historical reading. However, to make sense of the 
economic competences of the individual republics - the clear-cut economic prerogatives of which were discussed at the federal level throughout the 1970s, as is shown in minutes of federal government meetings quoted in this chapter - and how they shaped the way Western European economic integration was perceived in Yugoslavia, republican inputs at the federal level are deliberately emphasised. It is argued that, especially after the adoption of the 1974 constitution, dealing with Yugoslavia's foreign economic policy without considering the republican factor would overlook a constitutive element of Yugoslavia as it was in the late Cold War years.

\section{A liberal opening towards the EEC}

In September 1968, Yugoslavia became the first socialist country to enter into official diplomatic relations with the EEC. ${ }^{23}$ The decision to establish direct relations with the Community was the result of a foreign policy orientation which went back to the mid-1950s. Due to its dependence on Western technology and industrial equipment, Yugoslavia had manifested profound interest in early Western European post-war integration efforts and had therefore applied to the OEEC for observer status in December 1954, becoming an associate member of the organisation the following year. The Yugoslav authorities expected that associating with the OEEC would enhance exports to Western markets and integrate the country in intra-European trade. Indeed, already in the mid-1950s, the Yugoslav leadership regarded the country's external commercial imbalance as a pressing concern. ${ }^{24}$ The same economic rationale shaped Yugoslavia's early approaches to the European Coal and Steel Community (ECSC) and later the EEC. The goal was to preserve economic ties with the six founding members of the Community (the Six) and avoid economic isolation between the two regional economic blocs. Indeed, Yugoslavia did not ignore the economic weaknesses of the federation and its entanglement between the two European blocs. Its active participation in the official establishment of the Non-Aligned Movement (Belgrade, 1961) went hand in hand with a careful diplomatic balance between the Soviet Union and the Western partners.

As for the former, after the death of Stalin (1953) relations between Tito and the new Soviet leadership led by Nikita Khrushchev had fluctuated between moments of 'reconciliation, comradeship and confrontation'. ${ }^{25}$ The normalisation of diplomatic relations favoured the development of economic ties after Yugoslavia's post-1948 isolation. Economic relations with the CMEA area were grounded on a clearing system based on agreements on the exchange of goods and bilateral cooperation in the industrial field. ${ }^{26}$ The development of economic ties with the Soviet bloc countries, which represented the privileged market for Yugoslavia's industrial output, resulted in Belgrade's association with the CMEA in 1964. ${ }^{27}$

From the late 1950s, Yugoslavia's relationship with its Western European partners and the newly established EEC also followed a clear-cut economic rationale which reflected contemporary debates within the SKJ on the process of internal economic liberalisation. The establishment of the Community indeed coincided 
with a rise of internal divergences within the country's political leadership about the integration of Yugoslavia in the international economy. The party's liberal wing - which advocated an introduction of market mechanisms in the economic system and opening to the international market through attracting foreign investments - prevailed over the resistance of the party conservatives, who feared the political consequences of economic liberalisation. Famously, in December 1964 the League's Central Committee approved a first set of liberal economic reforms (which began to be implemented in 1965) with the goal of strengthening the technological basis of Yugoslav industry and increasing the country's participation in the 'international division of labour' ${ }^{28}$ The introduction of liberal reforms was paralleled by enhanced relations with the EEC. The leading actors in the 1965 economic reforms were indeed deeply interested in rising to the commercial challenge stemming from the constitution of the customs union and the launch of the Common Agricultural Policy (CAP) in the early 1960s. The first official exploratory talks with representatives of the European Commission took place in Brussels in 1965 and led to an official request for the conclusion of a trade agreement with the Community. Between 1967 and 1968, the goal of Yugoslavia's political leadership - led by the president of the Federal Executive Council (Savezno izvršno veće [SIV]); the Croatian Mika Špiljak, the secretary for foreign affairs; the Serb Marko Nikezić; 29 and the Serb Milentije Popović, the president of the Federal Assembly ${ }^{30}$ - was to secure access for its external output to the Common Market in order to strengthen the process of internal economic reform.

All in all, during the early and mid-1960s, the Yugoslav leadership followed a cautious and pragmatic course which resulted in a balanced relationship with the two leading regional economic blocs. ${ }^{31}$ This attitude reflected the structure of Yugoslavia's external trade, which was based on importing technology and industrial equipment from the Western European market and exporting industrial goods to the CMEA area. However, this equilibrium was precarious and uncertain, as it depended on the delicate balance of relations with Moscow. This balance started to change after the appointment of Leonid Brezhnev as secretary general of the Communist Party of the Soviet Union in 1964. With an orthodox turn impressed on Soviet foreign policy, ideological controversies with Yugoslavia resurfaced, and they exploded after the Warsaw Pact intervention in Prague in August 1968. Yugoslavia's open condemnation of the military intervention in Czechoslovakia and the brutal suppression of the Prague Spring marked a deterioration in relations with Moscow. ${ }^{32}$ The Yugoslav leadership feared that the Soviet decision to invade Czechoslovakia could herald a new phase of aggressive foreign policy which would soon involve the Yugoslav 'heresy'. The consequences of the Czechoslovak crisis primarily concerned fear of renewed economic isolation from the Soviet bloc area. ${ }^{33}$ In Moscow, Yugoslav diplomatic representatives were blamed for playing a 'double game' between the CMEA and the EEC. ${ }^{34}$

The Prague events marked a first step towards the politicisation of relations with the Community. On the commercial dimension, they acquired a broader political meaning which was openly manifested by Yugoslav representatives in Brussels (in particular, the Slovenian Miloš Oprešnik, Yugoslavia's first ambassador to 
the EEC from September 1968) and the capitals of the EEC member states. The Czechoslovak crisis was indeed a leitmotiv during the preparatory phases of trade talks on a commercial agreement with the EEC, which opened in October 1968. ${ }^{35}$ An overall agreement emerged on a deepening of relations with the Community, and no opposition arose in this regard within the League or the SIV. Indeed, the Czechoslovak events were only one of multiple factors determining the choice to accelerate negotiations with the Community; they were used as a political tool to convince the EEC member states to respond to commercial requests which had been made well before August 1968. The launch of the market-oriented reforms indeed resulted in massive imports of Western industrial equipment. At the same time, Yugoslavia's exports to the EEC (mostly agricultural products) had stagnated as a consequence of the CAP regulations. ${ }^{36}$ This resulted in an increase in the country's trade deficit (from 58 million US dollars in 1965 to 364 million US dollars in 1969), and a continual search for import credits from its Western European partners, particularly West Germany, Italy and France. ${ }^{37}$ Within this framework, republic-level banks played a prominent role in investment finance operations. ${ }^{38}$ Yugoslavia's economic reforms were also followed by a search for increased economic autonomy of the republics and autonomous provinces vis-à-vis the federal centre. This was particularly the case of Slovenia and Croatia, whose business elites advocated an expansion of relations with the Common Market countries, in particular West Germany (which in the late 1960s included Yugoslavia in its Neue Ostpolitik) and Italy. ${ }^{39}$

The opening towards the EEC was therefore a combination of liberal and republican interests. It was not by chance that the leading actor in commercial negotiations was the Slovenian Toma Granfil, a member of the SIV who had been in charge of relations with the EEC since 1968. Granfil was assisted by Boriš Šnuderl, also a Slovenian and a deputy secretary at the Federal Secretariat for External Trade (Savezni Sekretarijat za Spoljnu Trgovinu [SSST]). Both Granfil and Šnuderl were in close contact with Yugoslav industrial enterprises (particularly in Slovenia, Croatia and Serbia) and acted as links between them and the federal centre. What these enterprises requested through the republican chambers of commerce was an expansion of commercial and industrial relations with Italy and West Germany, an improvement of industrial relations with firms in Italy's northern regions (Lombardy, Veneto and Friuli-Venezia Giulia) ${ }^{40}$ and an expansion of technical cooperation and joint investments with West German firms. ${ }^{41}$ The idea that Yugoslavia's enterprises should benefit from closer contacts with the Common Market was widespread among liberal reformers in the country, among whom were Špiljak and Granfil. Within the SIV, the prevalent opinion was that Yugoslavia's first need was to resolve its trade deficit and expand exports of agricultural products (beef in particular), which accounted for about $40 \%$ of the country's total exports to Western Europe. ${ }^{42}$ Accordingly, during the negotiations with the European Commission representatives, Yugoslavia insisted on including an agricultural chapter in the future commercial agreement. ${ }^{43}$

The negotiations led to the conclusion of a three-year trade agreement in March 1970, the first between the EEC and a socialist country. It was based on 
a non-preferential approach, as Belgrade deemed that a discriminatory agreement with the Community would affect the federation's political stance within the NonAligned Movement. ${ }^{44}$ The Yugoslav negotiators linked this treaty to the success of the market-oriented reform process. The public discourse developed in the League's official newspaper, Borba, and the bulletin of the Chamber of Commerce of Yugoslavia, Export Journal, focused on the economic and commercial aspects of the negotiations and the need to overcome the EEC commercial barriers to favour the development of the country's industrial base and agricultural production. ${ }^{45}$ The link between the liberal reforms and the Western European integration question was also constantly underlined by Granfil to his Community counterparts, who he urged to respond to Yugoslavia's requests to defend its particular path to socialism and resist alleged pressure from Moscow. During a meeting in November 1968 with Jean-François Deniau, the European commissioner in charge of external economic relations, Granfil argued: 'It is important for reciprocal economic relations for Yugoslavia to be treated like other market-economy countries, to eliminate any [commercial] clause identifying Yugoslavia as a state economy, which would be wrong and politically and economically unjustified' ${ }^{46}$

\section{The end of the liberal narrative}

The liberal narrative which had characterised Yugoslavia's policy towards the EEC started to change when the post-1965 economic reforms were followed by a gradual crisis. Famously, between 1970 and 1971 an economic recession was followed by an uncontrolled rise in investment and inter-republican acrimony over the allocation of federal resources and contributions to the federal budget. ${ }^{47}$ What followed was a move from economic to political confrontation among the republics. The emergence of nationalist and separatist trends, especially in Croatia, seemed to indicate that the process of economic liberalisation was the agent responsible for centrifugal tendencies in the federation. Purges started in Croatia in December 1971 and widened to all the republics, taking in a broad spectrum of party leaders in Slovenia and Serbia who were accused of liberalism, 'managerialism' and 'technocratic bureaucratism' ${ }^{48}$ Within this context, the party's leading ideologue, the Slovenian Edvard Kardelj, launched an anti-liberal and anti-reform discourse reaffirming that self-management and democratic centralism were the cornerstones of Yugoslavia. ${ }^{49}$

In July 1971, some of the leading actors involved in negotiating the first trade agreement with the EEC were replaced with the setting up of a new Federal Executive Council led by Bosnian Džemal Bijedić. Šnuderl, Granfil's successor, confirmed Belgrade's interest in carrying out negotiations to renew the 1970 trade agreement (which was to expire in 1973). He was in close contact with the Executive Council of Slovenia and was always receptive to input from Ljubljana. ${ }^{50}$ Šnuderl followed the path previously set by Granfil, insisting on the need for Yugoslavia to develop relations with the Community according to a twofold logic: economic, given the EEC's commercial importance for Yugoslavia; and political, as the Community was emerging as a balancing factor between the two superpowers. ${ }^{51}$ 
Šnuderl's activism was facilitated by Tito's views on the Western European integration question, which had been clearly manifested during a diplomatic tour of Western European capitals (Paris, Bonn, Brussels and Rome) between 1970 and 1971. These diplomatic missions were conceived as the Yugoslav response to the process of international détente between the superpowers and the parallel proposal for a pan-European Conference on Security and Cooperation in Europe (CSCE) by the Warsaw Pact countries in March 1969. Tito nurtured ambivalent feelings towards the unfolding of international détente. On the one hand, he was in favour of a relaxation of international tension which would result in expanded possibilities for Yugoslavia's economic relations with both regional blocs. On the other hand, he feared that the bloc-to-bloc dialogue, which seemed to be confirmed by the CMEA's early attempts to enter into direct relations with the European Community, ${ }^{52}$ would result in economic isolation of Yugoslavia. ${ }^{53}$

After an intergovernmental summit held at The Hague in December 1969, the EEC underwent its first enlargement with three new member states and launched a programme of deepening and completion which, among other goals, aimed to make the Community an international actor able to speak 'with one voice' in the international arena. ${ }^{54}$ To avoid isolation from the enlarging EEC, Yugoslav diplomacy reframed its approach to the Community, insisting on the developing status of the federation. This was a propitious juncture, as the EEC was looking for a new relationship with the members of the Group of 77 (G-77) developing countries through its launch of the Generalized Scheme of Preferences (GSP) in July 1971, and at the same time the Non-Aligned Movement was becoming increasingly interested in the issue of economic progress for underdeveloped countries, as emerged during the Lusaka conference in September of the same year. ${ }^{55}$ Yugoslavia successfully requested to be included in the list of the GSP beneficiaries by stressing its economic underdevelopment and its need to benefit from the same trade preferences as the other members of the G-77. The "development" discourse also originated from a widespread awareness within the League that the post-1945 bipolar equilibrium was being challenged by the political weight of the developing countries. ${ }^{56}$

Linked to this development issue was renewed propaganda on self-management in Western Europe. Although the re-launch of self-management was based on strict criticism of the alleged negative effects of the liberal reforms (i.e. bureaucratisation and marketisation of the economy) and on internal economic dynamics (which will not be addressed here), self-management was nevertheless depicted in SKJ international propaganda as an innovative system able to overcome the contradictions of both capitalism and socialism. A clear-cut political nexus linked non-alignment, underdevelopment and self-management. These labels were all intended to attract the attention of progressive Catholic, socialist and social-democratic political leaderships, intellectuals and trade unions in Western Europe. Indeed, in the late 1960s and early 1970s, the issue of industrial democracy acquired new momentum in Western European public discourse after the rapid decline of the les trentes glorieuses. ${ }^{57}$ The SKJ was aware of this and tried to emphasise its particular social and economic system, financing publications, 
scientific symposia and international conferences with the participation of leading politicians and intellectuals from Western Europe. ${ }^{58}$

A close link was also established between self-management and non-alignment in propaganda, and the northern republics made parallel calls for further economic relations with the Common Market. This was particularly the case on the occasion of a visit by the president of the European Commission, Sicco Mansholt, to Belgrade in December 1972. Mansholt, a Dutch social-democrat who had been deeply involved in the Community's relations with the developing world, ${ }^{59}$ was an ideal interlocutor for Yugoslavia. Indeed, Šnuderl, who had planned the European Commission president's visit, ${ }^{60}$ openly advised Tito's head of cabinet, his Slovenian comrade Marko Vrhunec, that self-management should be at the very core of Tito's conversation with Mansholt, given the latter's interest as a socialdemocratic leader in Yugoslavia's self-managed economy. ${ }^{61}$ Šnuderl's suggestion was accepted, and both Tito and Kardelj discussed the issue of Yugoslavia's 'modernity label' of self-management during Mansholt's visit. ${ }^{62}$

As the SIV member in charge of relations with the EEC, Šnuderl was also in direct contact with the SSST, the senior officials of which - in particular deputy federal secretary Milica Žiberna - represented a continuity factor in Belgrade's stance towards the EEC (she had been involved in the negotiations on the 1970 agreement with the Community). Šnuderl and Žiberna were aware of increasing pressures from the republican chambers of commerce and individual enterprises, in particular in the federal republics of Slovenia and Croatia, for closer links with the Western European markets to be established. Žiberna was in direct contact with the directors of enterprises and constantly informed them about the export/ import regime with the Community and the working of the GSP. She and her deputy, Petar Tomić, were veritable links between the business world and the state apparatus. ${ }^{63}$ Together with a number of officials from the SSST, Žiberna authored one of the first major publications explicitly dealing with the issue of Western European economic integration. ${ }^{64}$ In this book, the authors underlined Yugoslavia's dependency on Western European technology and know-how and related problems concerning the country's balance of payments. The book, as its authors explicitly stated, was intended to be a guide for Yugoslav enterprises, chambers of commerce and regional banks to better integrate with the Western European economic system.

The volume had symbolic importance as it inaugurated a series of contributions from the Yugoslav academic world on the question of European integration that paid prominent attention to individual policies and initiatives of the EEC, such as the CAP, the development of regional policy and monetary integration. ${ }^{65}$ However, given their specialised nature these studies did not develop into a true public debate ${ }^{66}$ Yugoslavia's academic elite's contribution on the country's stance towards Western European integration during the 1970s was therefore limited. Unlike what had happened during the 1960s, when studies on the EEC had contributed to political decision-making in dealing with the Community, politicaleconomic analyses concerning economic integration in Western Europe during the 1970 s were mostly carried out by the very people who were actually involved in 
official policymaking towards the EEC, or who collaborated with state-led organisations and agencies, such as the Institut za Medjunarodnu Politiku i Privredu (Institute for International Politics and Economy). This was particularly the case of articles published during the 1970s in Medjunarodna Politika (International Politics). ${ }^{67}$ As Ljubiša Adamović, chair of international economic relations at the University of Belgrade between 1972 and 1992, retrospectively argued, only in the late 1980s did Yugoslav scientific circles resume interest in the European integration question by virtue of the deep interest of Yugoslav society and the economic and political elite in the single market project. ${ }^{68}$

The prominent role of the state apparatus in dealing with the question of Western European economic integration confirmed the SIV as the main forum of debate. As the minutes of its meetings between 1972 and 1973 reveal, confrontation on this issue involved two alternative views. Šnuderl and his fellow representatives from Slovenia (Anton Vratuša and Janko Smole) advocated a qualitative step towards expanding commercial and economic cooperation relations with the Community. ${ }^{69}$ Šnuderl favoured direct relations with the European Commission, which had proved to prefer a more comprehensive approach to Yugoslavia according to an extensive interpretation of the Community's common commercial policy. However, Slovenia's proactive stance was not welcomed within the SIV, and in June 1972 Vratuša complained of an absence of a definite federal platform for enhancing relations with the EEC and of the ambivalent attitude of the Federal Secretariat for Foreign Affairs (Savezni Sekretarijat za Inostrane Poslove [SSIP]) on this matter. ${ }^{70}$ Indeed, a more conservative faction, headed by Bijedić, was sceptical about strengthening the supranational dimension of European integration and favoured the preservation of Yugoslavia's balance between the Community and the CMEA. ${ }^{71}$ Bijedić's stance was also linked to a parallel reshuffling of Yugoslavia's relations with the Soviet Union, sanctioned by a visit by Brezhnev to Belgrade in September 1971, against the backdrop of centrifugal tendencies in the federation and the purge of Croatia's leadership. ${ }^{72}$

However, the importance of the Common Market for Yugoslavia's external commerce was not questioned. In late 1973, Western European countries (the EEC plus the EFTA) represented Yugoslavia's main partner (accounting for $47 \%$ of its exports and $54 \%$ of its imports). Conversely, commerce with the CMEA countries lagged behind (34\% of its exports and $25 \%$ of its imports). ${ }^{73}$ The confrontation between Šnuderl and Bijedić did not result in an overt clash, and in the following months no clear-cut opposition to Šnuderl's initiatives emerged within the SIV. The Slovenian representative successfully insisted on including economic cooperation provisions in the fields of industry and agriculture in the new commercial agreement with the EEC, which was signed in June 1973. In parallel, on 18 April 1973 a non-preferential agreement on textile exports from Yugoslavia to the Common Market was also concluded. Prominent input in this direction had come from Yugoslav textile producers, mostly based in Slovenia. ${ }^{74}$

The period 1971-73 was marked by overall continuity in terms of Yugoslavia's relations with Western Europe and the EEC in particular. When the trade agreement with the Community was renewed in June 1973, Medjunarodna Politika reported 
that the SIV had succeeded in securing the Community's support for the country's internal and international status. However, beyond the official propaganda, the making of the 1973 agreement manifested profound differences from the previous one. The liberal discourse on the modernisation drive which had accompanied the negotiations on the 1970 agreement had faded, and with it efforts by Yugoslavia's leadership to enhance the country's competitiveness in the international market. As a consequence, the development discourse was promoted. It emphasised the need for Yugoslavia to be assisted economically through commercial concessions and the GSP. Moreover, the preparation of the 1973 trade agreement highlighted the emergence of specific republican interests in the EEC. However, contradictions in Yugoslavia's approach to the Community were to surface rapidly in the aftermath of the post-1973 economic recession in Western Europe.

\section{Playing the underdevelopment card}

The year 1974 marked the approval of a new constitution which confirmed the self-management system, later strengthened by the Associated Labour Act of 1976, as the cornerstone of the country's economic organisation. This reform process attributed a high degree of independence to the newly established 'organisations of associated labour' in all their business dealings and transactions with foreign partners. Enterprises were free to engage in operations involving the transfer of goods and capital and involving production and financial cooperation with foreign firms. Self-management provisions also assigned greater room for manoeuvre to the federal republics, which were now given broad exclusive competences in the fields of income distribution, taxation, employment, welfare policy and foreign trade. Instead, foreign policy and relations with international organisations, including the EEC, remained within the federal domain. However, according to the newly approved constitution, decision-making was based on negotiation and agreement among the republics and autonomous provinces. ${ }^{75}$ After 1974, the SIV became a clearing house for inter-republican confrontation and the major task of preserving the unity of the Yugoslav market (Art. 381 of the 1974 constitution) was subject to such confrontation.

The growing weakness of the SIV coincided with the explosion of a global economic recession in the aftermath of the 1973 oil shock. On a proposal by Italy and France, the EEC issued protectionist measures suspending the provisions of the 1973 trade agreement to face competition from Yugoslavia's agricultural exports. ${ }^{76}$ At the same time, the rising cost of oil made imports from Western Europe more expensive. From 1968 to 1972, imports of mineral fuels accounted for about $5.5 \%$ of the country's total imports. In 1974, this percentage rose to $12.6 \%$, heralding a growing trend which would culminate at $23.5 \%$ in 1980 in the immediate aftermath of the second oil shock. ${ }^{77}$ At the same time, a decrease in internal demand in the Community meant restrictions in the labour market. A massive return of Yugoslav guest workers from West Germany exacerbated the balance of payments problems. After the oil shock, the country was also hit by the availability of international credit. Like the vast majority of developing 


\section{2}

countries in Eastern Europe, it was 'kissed' by debt. ${ }^{78}$ Aiming to expand domestic credit, Yugoslav banks started the practice of borrowing abroad and converting the credits into dinars. Constitutional provisions limited the capacity of the SIV to manage the balance of payment problems, impose any kind of strategic pattern on the flood of foreign borrowing and foster a homogeneous import policy. Successive reforms in the foreign trade system, later sanctioned by a 1977 Law on the Turnover of Goods and Services with Other Countries, ${ }^{79}$ created a complex interest network, based on self-management planning of foreign economic relations, which put workers in organisations of associated labour in the focus of economic decision-making in the sphere of foreign exchange operations. ${ }^{80}$ This had a clear impact on the country's export policy and, in turn, on relations with the EEC.

The individual republics - Slovenia and Croatia in particular - stepped up pressure to get the maximum advantage from negotiations with the European Commission to improve access to the Common Market (in particular to West Germany and Italy). ${ }^{81}$ The Republican Secretariat for Agriculture and Forests in Ljubljana in particular manifested attention to the development of agricultural relations with the Common Market, ${ }^{82}$ whereas the decorative fabrics factory in Ljubljana (Tovarna Dekorativnih Tkanin) ${ }^{83}$ and the Textil company based in Zagreb insisted on broader concessions for the textile industry. ${ }^{84}$ At the business association level, the Association of Yugoslav Iron Workers in Belgrade (Udruženje Jugoslovenskih Železara) paid particular attention to the EEC's preferential scheme, ${ }^{85}$ openly insisting on closer cooperation between Yugoslavia and the Community in the industrial domain. ${ }^{86}$ These calls were results of the industrialisation process which, to face international competition during the 1960s, had turned Yugoslavia from an agricultural into an industrial country. The agricultural population had decreased from 51\% to 38\% of Yugoslav workers between 1961 and 1971, and over the same period the share of agriculture in Yugoslavia's total exports had fallen from $38.1 \%$ to $19.6 \%{ }^{87}$ This process would characterise the Yugoslav federation's patterns of trade throughout the 1970s: in 1980 agricultural exports would only represent $11.39 \%$ of the country's exports. ${ }^{88}$

The huge impetus for increased relations with the EEC was confirmed by the pressure exerted by the Slovenian and Croatian economic elites for settlement of the border issue with Italy. The two republics' chambers of commerce promoted a joint action which called for increased border cooperation with Italy's northeastern region as a doorway into the Common Market. In direct contacts with the Slovenian leadership, Šnuderl himself conducted secret negotiations which were to lead to the Osimo agreements between Rome and Belgrade signed in November 1975. ${ }^{89}$ This agreement solved the border problem between the two countries, a troubled legacy of World War II. It envisaged the creation of a cross-border industrial zone between Italy and Yugoslavia from which Slovenian and Croatian industrial produce could enter the Community without tariff restrictions. After the signing of the Osimo agreements, and on the basis of the confederal provisions in the 1974 constitution, Slovenia and Croatia fostered bilateral cooperation with bordering regions. In November 1978, this led to the constitution of the AlpsAdriatic Working Community as a means to foster regional cooperation with Italy 
(Friuli-Venezia Giulia and Veneto) and Austria (Carinthia, Upper Austria and Styria) in the fields of culture, science, transport and tourism. ${ }^{90}$

Given the pressure from the northern republics and the parallel crisis in commercial relations with the EEC, debates on the Western European integration question acquired new momentum. Yugoslavia's unbalanced dependency on the Common Market was highlighted within the SIV. While the Federal Secretary for Finance, Montenegrin Momčilo Čemović, openly accused Italy (which had first proposed the Community ban on beef imports from Yugoslavia) of 'stabbing Yugoslavia in the back', Šnuderl insisted on a less emotional approach to their Western European partners and on the need to expand cooperation well beyond the commercial sphere to avoid dependence on the nine members of the EEC (the Nine). ${ }^{91}$ Conversely, the political side of relations with the EEC was underlined by the League's leadership (particularly Tito and Kardelj) and the SSIP, which after the 1972 purges of the liberals in Serbia was led by Serb Miloš Minić, a veteran member of the League and one of Tito's closest comrades. The party elite was mostly interested in the EEC's role in foreign policy as an international actor and how it could match the country's non-aligned stance. The launch of an intergovernmental scheme for foreign policy cooperation (EPC) among the EEC member states in 1970 and the Nine's proactive stance during the CSCE preparatory phase confirmed the Community's ambitions in the international arena. ${ }^{92}$ In addition, the SSIP closely monitored the development of direct relations between the EEC and the People's Republic of China, depicting them as a demonstration of the Community's increasing international weight. ${ }^{93}$ At the same time, the SKJ and the SSIP were concerned about the effects of the balance of trade disequilibrium on the financial stability of the federation. In this regard, they were also supported by Bijedić, who strove to balance competing republican interests. The Slovenian and Croatian activism towards the EEC, which had clearly emerged during the negotiations on the Osimo agreements, indeed arose the concerns of the Federal Secretariat for the Economy, led by the Serb Boško Dimitrijević, that a privileged border regime with Italy - based on finished products drawing on raw materials or semi-finished goods coming from the central or southern republics which could not, in turn, enjoy the economic advantages of the northern republics - would enhance economic disparities within the federation. ${ }^{94}$

Minić advanced requests for the relaunch of commercial relations with the Community during an official visit to Brussels in November 1974. Once back in Belgrade, Minić reported his personal apprehensions during a meeting of the SIV on 30 December 1974. He underlined the payment problems which Yugoslavia would face should the deterioration of the trade balance in relations with Western Europe continue. ${ }^{95}$ For his part, Bijedić agreed on the importance of closely examining the evolution of the balance of payments. ${ }^{96}$ In the following weeks, appeals for enhanced cooperation with the EEC partners were also issued by Ivo Kuštrak, the president of the Federal Committee for Agriculture and formerly the vice president of the Chamber of Commerce of Croatia. In January 1975, he argued: 'The ratio between imports and exports is 1 to 3 . This is not negligible. I am saying this because we are severely hit in the agricultural sector and we must look for a way out, not only for agriculture but for the country as a whole' ${ }^{97}$ 
Kuštrak's inputs were supported by the Federal Secretary for External Commerce, the Croatian Emil Ludviger, who insisted on a pragmatic approach towards the Community based on a step-by-step policy. He was against an overall strategy encompassing 'economy, finance, social policy, monetary policy. . . . this would be pretentious on our part. ... We must be realistic about what to expect from this [European] Community'. ${ }^{98}$ Following Ludviger's appeal, a pragmatic initiative started to develop to enlarge financial cooperation with the European Investment Bank (EIB).

This initiative was once again an outcome of lobbying by Slovenia. Indeed, already in 1973 the Federal Secretariat for Finance under the leadership of Secretary Janko Smole had explored the possibility of Yugoslavia having access to EIB loans. ${ }^{99}$ Smole had been fully supported by his Slovenian comrade Šnuderl as both regarded financial cooperation with the Community on infrastructure projects as a fundamental means for further integrating the Yugoslav federation, and Slovenia in particular, with the Common Market. ${ }^{100}$ Appeals for financial cooperation were reiterated during a ministerial meeting of the EEC-Yugoslavia Mixed Commission in July $1975 .{ }^{101}$ In this instance, the initiative was taken by Smole himself, who had meanwhile replaced Šnuderl, due to the latter's divergences with Bijedić over the EEC question, ${ }^{102}$ as the SIV member in charge of relations between Yugoslavia and the Community.

After the aforementioned preliminary approaches in the financial field, Smole realised that a broader political mandate from the SIV was needed to foster his initiative. On 23 October 1975, he clearly stated to his peers that a federal strategy should be inaugurated to convey an external image of Yugoslavia as a reliable partner. ${ }^{103}$ 'The EEC member states', Smole argued, 'believe that the issue of commercial deficit only depends on us, that this is a question of Yugoslavia's political economy'. ${ }^{104}$ Smole therefore did not present financial cooperation as a Slovenian project but, being aware that the political aspect of the EEC question was of primary importance for the SIV presidency and the SKJ, he argued that Yugoslavia should demonstrate its interest in taking initiatives to overcome the present impasse. The political battle for financial cooperation was to be the starting point for extended collaboration in the field of commerce, tourism and joint ventures. Čemović argued that Smole's initiative should be followed up and that concrete proposals for financing joint projects should be made. Čemović also claimed during the debate that increasing republican competences in the field of logistics investment were hindering the creation of genuinely federal infrastructure networks. He stressed that Yugoslavia's major aim was to get financing for the creation of a highway linking Slovenia (Ljubljana) to Macedonia (Djevdjelija). Such financial support would have a political meaning. By investing in the unity of the country as a whole, Yugoslavia (as a federal and homogeneous entity) could be recognised as a strategic partner by the EEC member states as a bridge towards Greece and the Arab world. Thanks to Čemović's support, based on a federal perspective which, however, did not challenge the Slovenian requests, Smole's proposal for enhanced financial cooperation with the Community was approved by the SIV. The appeals by the federal government for the establishment of financial 
cooperation were finally accepted by the Council of Ministers of the EEC in January 1976, paving the way for the launch of projects of joint interest from 1977 onwards, including the financing of five sections of the future trans-Yugoslavia motorway. ${ }^{105}$

Beyond the financial sphere, a political initiative to face the question of trade relations with Western Europe was reappraised by Bijedić during a meeting of the SIV on 3 December 1975. The SIV met to review the state of the federal balance of payments, as the dreadful situation depicted by Minic the previous year had not improved. The growing trade deficit was threatening Yugoslavia's economic links with the West, a situation which, in Bijedić's words, could not be passively accepted: 'We cannot detach from the West so easily. Neither will we have to because this is our traditional market for imports and exports and we need to plan an organised economic strategy'. ${ }^{106}$ Bijedić therefore called for increased diplomatic pressure on Western European partners to invest in Yugoslavia. He insisted, however, that such assistance should be based on direct pressure from the directors of Yugoslavia's major enterprises. Western partners should be literally urged to buy Yugoslav goods. This was the case, for example, of relations with Italy. Bijedic stated that, by virtue of traditional links in the automobile sector established by FIAT and ZASTAVA in Kragujevac, the influential president of FIAT, Giovanni Agnelli, should urge the Italian government to adopt a more liberalised commercial stance towards Yugoslavia: 'Let's make Agnelli help us sell 20,000 tons of meat and that would already be a good deal. Let's make him fight with the Italian government in order to make it buy [meat]'. ${ }^{107}$ According to the president of the SIV, Yugoslavia could hardly compete on economic grounds: 'It is capitalism: they tend to preserve their own interests'. ${ }^{108}$

The relationship with the Community was therefore increasingly intertwining with the trade deficit problem. During a meeting of the SIV in early January 1976, Minić defined the country's commercial imbalance as Yugoslavia's 'most important foreign policy issue'. At the same time, he noted a stark increase in trade relations with Eastern Europe: 'The question arises as to where we are actually going'. ${ }^{109}$ Minić's attitude was marked by profound pessimism, which echoed Bijedić's previous statements: 'In our economy . . . there is not the capacity to compete within the markets of developing countries, whereas all our weaknesses can be sold in the East'. He defined the CMEA area as a second-ranking market which was ready to accept low-quality technology, 'something which the Western market cannot tolerate'. 'We must import', Minić continued: 'This is the real state of our economy and we must find ways . . . to increase exports. . . . This issue is linked to our political independence, to our position in the international political scene. The state of our exports to the Western market is unbearable'. ${ }^{110}$ Minić therefore called for new diplomatic initiatives towards the Western European partners and the European Community to overcome commercial barriers. Similar concerns were echoed by Milorad Birovljev, a Serb from Vojvodina who chaired the Federal Committee for Social Planning. Birovljev expressed his alarm at the federal weakness in managing import and export strategies due to the direct competence of the republics and autonomous provinces in this field. At the same 
time, he underlined a need for a political action towards Western European governments. The Serb Berislav Šefer, a vice president of the SIV, spoke of the bad situation of the balance of payments and the 'politically dangerous' reflection of this situation on the country's international image. He agreed with Minic that the penetration of Yugoslavia's exports in the Common Market should be increased. However, beyond general statements on the need to foster exports, this debate was characterised by an overall disillusionment about the possibility of changing the course of Yugoslavia's economic policy. This was explicitly manifested by Bosnian Gojko Ubiparip, who argued: 'We are debating about exports . . . to the Western markets. . . . we are debating and finding reasons for our economic recession. However, we are not considering our internal disorganisation and the lack of planning. There are no plans in the country and we do not know what our strategy is'. Šefer agreed with Ubiparip and underlined the need for the federal authorities to find a way to manage the uncontrolled flow of financial credits to finance imports. ${ }^{111}$

After this disconsolate debate, the SIV paid increasing attention to the evolution of a federal posture towards the Common Market. In February 1976, Bijedić made a diplomatic tour to Paris, Luxembourg and Brussels. During the visits, he spoke of the political importance of relations with the Community and the need to solve the trade deficit question. The decision to make the EEC a political partner to face the question of the country's internal stability led to the conceptualisation of a joint declaration to be signed by Yugoslavia and the EEC. As the archival sources reveal, negotiations on this were entirely dealt with at the federal level and were strongly supported by Bijedić. The tightly knit inter-ministerial group which was set up to prepare the draft text to be submitted to the Community counterparts was made up of members of the SSIP (Božidar Frangeš), the SSST (Milica Žiberna) and two diplomats in the Yugoslav mission to the EEC in Brussels (Žarko Tomašević and Časlav Djermanović). ${ }^{112}$ The declaration was signed on 2 December 1976 by Bijedić and Max Van der Stoel, the Dutch foreign minister and president of the Council of Ministers of the EEC. ${ }^{113}$ The 1976 Joint Declaration affirmed Yugoslavia's non-alignment and developing status as the cornerstone of bilateral relations between the two parties. This was a clear input coming from the SSIP. ${ }^{114}$ Publicly, the 1976 declaration was presented as a success for the Yugoslav federation, as it reaffirmed the principles and character of its foreign policy and particularly the country's standing as a 'non-aligned, socialist and developing country with a distinctive socio-economic system based on the principles of self-management socialism' ${ }^{115}$

The rationale behind the Yugoslav stance towards the EEC after the signing of the joint declaration confirmed the foreign policy dimension of Yugoslavia's opening towards the Community. Yugoslav representatives from the SKJ and the SIV - which was now led by the Montenegrin Veselin Djuranović after the premature death of Bijedić in January 1977 - were increasingly aware that the high investment rate which had characterised the country throughout the 1970s was not sustainable. A sort of 'prisoner's dilemma' was emerging within the federation, with each republic benefiting from autonomous import regimes to the detriment 
of the federal balance of trade. In fact, a 'Resolution on the Realisation of Yugoslavia's Social Plan for 1978', which was approved by the parliament on 28 December 1977, provided that import substitution programmes should be adopted in the course of 1978. However, unfavourable market conditions in the Western countries and the orientation of domestic producers towards the internal market, in which high prices in comparison with the world market could be obtained, compromised this effort. To face the trade deficit, a change in Yugoslavia's policy towards the Community was agreed and the traditional non-preferential commercial approach had therefore to be overcome. This policy change was manifested by Djuranović during a meeting in Belgrade with the vice president of the European Commission, Wilhelm Haferkamp, in June 1978. ${ }^{116}$ On this occasion, the SIV president stated that the Nine should defend Yugoslavia's non-aligned status, and that to do so a new sui generis commercial regime should be set up to assist the federation with unilateral trade concessions well beyond the GSP. ${ }^{117}$ This policy change modified the non-discriminatory approach endorsed by the Yugoslav leadership since the negotiations for the 1970 agreement. All in all, this was the consequence of the incapacity of the SIV to impose a working import substitution policy. ${ }^{118}$ The aforementioned 1977 foreign trade reform had even deteriorated the coordinating role of the SIV. Retrospectively, improving relations with the EEC was a way to solve the trade deficit situation while avoiding internal reforms.

Djuranović's move was openly sponsored by the SKJ leadership. In December 1978, Tito explicitly declared his country's weakness and dependency on the West while meeting with the secretary general of the Organisation for Economic Co-operation and Development (OECD), Emiel van Lennep. In 1977 the OECD countries represented $51 \%$ of Yugoslavia's total trade, $77 \%$ of its commercial deficit and $87 \%$ of its foreign debt. Tito therefore made an appeal for economic assistance on the basis of Yugoslavia's status as a developing country. In particular, he made it clear that in the long run Yugoslavia could not stand a policy of high investment and foreign indebtedness. He therefore asked for Western understanding of Yugoslavia's precarious state. Referring to the debt question, Tito argued, 'We are continuing to buy goods in Western Europe which are necessary for our development. I do not know for how long this may go on' ${ }^{119}$ Tito's statements were frequently raised by senior representatives of the SKJ, particularly Vladimir Bakarić, in bilateral contacts with West German representatives. ${ }^{120}$ According to Bakarić, relations between the EEC and Yugoslavia should mainly comprise and be understood within the broader context of north-south relations and the EEC's development policy. ${ }^{121}$ It was not by chance that at the level of the League's International Commission, discussions centred on topics such as the new international economic order and the critical role of Western Europe in it - indeed, criticism of EEC protectionism had been clearly made in the final conclusions of the Fourth Non-aligned Summit in Algiers in September $1973^{122}$ - rather than on the actual dimension of economic relations between the Community and Yugoslavia or the federation's internal plans to face the rising commercial deficit. ${ }^{123}$ This attitude also reflected the stance adopted by SKJ representatives during the preparatory phases of the Conference of European Communist Parties held in Berlin in June 
1976. On an initiative of the Italian Communist Party, representatives of several Western and Eastern European communist parties had gathered in Rome on 19-20 April 1975 to review the 'contemporary status, possibilities and prospects for economic cooperation in Europe'. While the representatives of the Eastern European parties limited themselves to blaming the discriminatory nature of the Common Market, Milan Aleksić, a member of the SKJ Presidency and director of the Belgrade-based Institute for Foreign Trade (Institut za Spoljnu Trgovinu), stated that economic cooperation in Europe should not neglect the broader necessity of reforming the international division of labour and relations with developing countries. ${ }^{124}$

However, the north-south issue and the coordination among developing countries had less impact on Yugoslavia's relations with Western Europe than the continual deterioration of the trade balance and the increasing foreign indebtedness. The lack of a federal economic strategy was even emphasised by the sheer absence of communication between the SIV and the republics and autonomous provinces of statistics on the actual flow of financial credits from the West, as emerged during a meeting of the SIV on 19 March 1979. ${ }^{125}$ Macedonian Stojan Andov, who replaced Smole as the person in charge of the SIV Commission for Relations with the EEC in May 1978, worked towards a politicisation of relations with the Community. During a meeting of the SIV on 10 May 1979 he argued, 'It is important to regulate our relations with the EEC for the economic stability of the country, as the economic stability of the country is important for its overall position in international relations'. ${ }^{126}$ Negotiations between Belgrade and the European Commission concerned the conclusion of a sui generis cooperation agreement. On the Yugoslav side, they were carried out by Andov on the basis of this clear-cut political rationale, which was later underlined by the Soviet invasion of Afghanistan in December 1979 and the rapid deterioration of Tito's health in January 1980. ${ }^{127}$ Croatian Josip Vrhovec, who had replaced Minić as foreign minister in 1978, was instead de facto excluded from the negotiations between Belgrade and Brussels. The SIV as a whole was only consulted when the guidelines for the platform for negotiations were discussed in spring 1979 and when the treaty was ready to be signed in February 1980. Communication with the members of the federal government was therefore kept to a minimum level and the question was treated as a state secret. During the final negotiating phases, many of the SIV members, including Vrhovec, lamented the overall lack of information about the whole process. ${ }^{128}$ All in all, the conclusion of the 1980 agreement developed without comprehensive economic and political debate within the federation and the republics.

The 1980 cooperation agreement with the EEC was finally signed on 2 April, a few weeks before the death of Tito on 4 May 1980. Belgrade was granted unilateral and non-reciprocal commercial concessions in both the agricultural and industrial fields. ${ }^{129}$ Provisions on economic cooperation in the fields of tourism, environment, finance and industrial cooperation were also included. However, beyond the commercial sphere, the provisions of the agreement were general and indicative. As Andov himself stressed in Medjunarodna Politika, Yugoslavia's opening 
to the Community was primarily linked to the country's status as a developing country which had to depend on Western European commercial concessions. ${ }^{130}$ The rise in the trade deficit and the growth of Yugoslav overall foreign indebtedness (from 3.5 billion US dollars in 1972 to 18.4 billion US dollars in 1980) ) $^{131}$ against a backdrop of sky-high oil prices and rapidly escalating rates of interest on international credit bore witness to such dependency. However, relying on a policy of assistance and concessions was exposing Yugoslavia to increasing dependency on the Common Market and the goodwill of Western European leaders. It seems that the Yugoslav leadership artificially separated the European integration question from its internal economic dimension. The preconditions for the link between Yugoslavia's performance at home and abroad, which hugely impacted the country's economic balance at the end of the decade, were definitively set, as was its entry into the financial spiral which would lead to the debt-service crisis and successive IMF restructuring programmes from 1982 onwards. ${ }^{132}$

\section{Conclusions}

During the long 1970s, Yugoslavia's policy towards the EEC was the result of a complex set of diverging dynamics. The establishment of relations with the Community and the making of the first trade agreement in 1970 were outcomes of a process of liberal reforms. The "realistic" opening towards the EEC, which distinguished Yugoslavia from the Soviet bloc countries, was therefore grounded on economic considerations which pointed at the need to avoid the negative consequences of the customs union established by the Six and foster economic relations with the Common Market. While the Warsaw Pact intervention in Prague and its international repercussions highlighted the political dimension of EEC-Yugoslav relations, the liberal rationale of the commercial negotiations which officially opened after October 1968 did not change. However, also as a consequence of the market-oriented reforms and political opening to the Community - which was then experiencing a triple process of enlargement, deepening and completion - during the negotiations on the first trade agreement (1968-1970), specific economic interests of the economic elites of Slovenia and Croatia began to take shape. As was highlighted in the second section of this chapter, the crisis resulting from the liberal reforms also involved the course of Yugoslavia's opening towards the EEC. This opening was conditioned by the emergence of inter-republican competition and the successive confederalisation of the country with the adoption of the 1974 constitution. Within this framework, competing views between the federal approach adopted by the SKJ and the SIV presidency and the republican prerogatives of Slovenia and Croatia emerged. While the former advocated a political reading of relations with the EEC - based on Yugoslavia's status as a non-aligned and developing country and the rising international role of the Community within the framework of the CSCE - the latter were instead interested in the economic advantages which the republics would draw from closer ties with the Common Market. The two views became irreconcilable after the economic recession which hit Western Europe in the aftermath of the 1973 oil shock and the 
adoption of the 1974 constitution. While the commercial and economic dimension of relations with the EEC was sponsored by the republican leadership, the political view of relations with the Community endorsed by the SKJ, SSIP and SIV presidency (Bijedić and from 1977 onwards Djuranović) gradually prevailed. The view of the EEC as a political rather than economic partner suited the foreign policy orientation of the League's leadership - as it focused on the Western European attempt to prevent a superpower condominium in Europe - and was functional in maximising the strategic value of a united Yugoslavia in Western eyes. Overall, the opening to the EEC, which had started within the framework of the reformist policies of the 1960s in order to integrate Yugoslavia in the international economy, turned into a conservative policy to preserve the federation's internal and external status quo. From the viewpoint of the Yugoslav federal leadership, the EEC member states had to assist Yugoslavia's policy of high investment and exports to the Common Market. The short-term aims were to get convertible currency from the West, solve the trade deficit and sustain the confidence of Western creditors. To justify this policy internally and abroad, Yugoslavia's official narrative was that of an underdeveloped country assisted by developed economies. Indeed, the negotiation of the 1980 cooperation agreement with the EEC was the outcome of a pessimistic outlook on the capacity of the country to stand integration in the international economy and balance internal investment with foreign exports. Once the political aspect of the negotiation prevailed over its economic rationale, Yugoslavia condemned itself to a policy of dependency on Western Europe, confirming its isolation at the periphery of the Common Market. At the turn of the decade from the late 1960s to the late 1970s, the Yugoslav federal elite had thus moved from the illusion of an industrial future to an apologetic description of the federation as an underdeveloped country which hid its growing structural disparities.

While this study has not addressed the origins of the collapse of Yugoslavia in the early 1990s, which took place in a different international context, it has addressed the lack of a veritable federal strategy vis-à-vis the EEC, and the impossibility for the federal government to shape the country's foreign economic policy, which was considered an object, rather than a subject, of the globalised economy of the 1970s. We can see here the long-term roots of Yugoslavia's uncontrolled spiral of commercial and credit imports and the ever-declining role of the federal government vis-à-vis the federal republics, which Ante Marković's reforms in the late 1980s were not able to correct.

Comparatively, the sui generis character of Yugoslavia's relations with the EEC proved to be nominal rather than substantial. Yugoslavia's official recognition of the Community and the conclusion of official agreements with it - a unicum in relations between the Community and the socialist world which would only be followed by the People's Republic of China in the late 1970s - did not mean the country was actually included in the integration path of Western Europe, nor did it imply a process of EEC-inspired political and economic liberalisation in the country. Internal political dynamics shaped the rapprochement to the EEC rather than vice versa. Instead, the story told in this chapter shows the impressive 
similarity of the Yugoslav case with those of the other socialist states addressed in this book, in that unbalanced trade relations, determined by an import hunger for high-quality machinery and equipment in the absence of an endogenous drive for exports, and a chronic deficit of the balance of payments were concerned (as in the case of Bulgaria in the late 1970s and Poland, Romania and the GDR at the beginning of the 1980s). ${ }^{133}$ Equally similar to the dynamics experienced by the CMEA member states were Yugoslavia's attempts to move to less centralised market socialism (Hungary), to play the development card to obtain commercial concessions (Romania) and to rely on Western financial credits to foster internal investment (in particular, the GDR, Hungary, Poland and Romania). Finally, this work has highlighted the internal effects of Yugoslavia's inclusion in the global economy in terms of import-based investment, uncontrolled access to foreign credits after the 1973 oil shock and dependency on fluctuations in interest rates, which made the country part of the broader group of underdeveloped countries in Eastern Europe and Latin America which later underwent the global debt crisis of the 1980s. ${ }^{134}$

\section{Notes}

1 On the origins of self-management, see Unkovski-Korica, The economic struggle for power in Tito's Yugoslavia.

2 Rajak, "From regional role to global undertakings," 65-86; Jakovina, Treća Strana.

3 See Perović, "The Tito-Stalin split," 32-63; Rajak, Yugoslavia and the Soviet Union in the early Cold War.

4 Zaccaria, The EEC's Yugoslav Policy.

5 Lees, Keeping Tito afloat; Heuser, Western 'containment'policies; Bekić, Jugoslavija u Hladnom ratu.

6 Kramer, "Stalin, the split with Yugoslavia," 29-63.

7 Uvalić, Investment and property rights in Yugoslavia.

8 Obadić, "A troubled relationship," 337-39.

9 Obadić, In pursuit of stability; Bianchini, La diversità socialista in Jugoslavia, 57-70.

10 The most recent studies on Yugoslavia's views on the EEC based on Yugoslav archival sources have addressed the 1970s only tangentially, and in view of the consequences of the reforms launched in the 1960s. See Obadić, "A troubled relationship," 329-48; Dragišić, "Jugoslovenski pogledi," 147-60; Ruzicic Kessler and Dragišić, "Zwischen Chance und Bedrohung," 138-56. This offers an analysis of YugoslavEEC relations at the institutional level without systematically investigating internal debates among the Yugoslav elite.

11 Zaccaria, The EEC's Yugoslav Policy.

12 Woodward, Socialist unemployment; Ramet, The three Yugoslavias, 325-40; Dyker, Yugoslavia.

13 Calic, "The beginning of the end," 66-86.

14 Woodward, Socialist unemployment.

15 Lampe, Prickett, and Adamović, Yugoslav-American economic relations.

16 Kosanović, "Brandt and Tito," 232-43.

17 Zaccaria, La strada per Osimo; Mišić, Pomirenje na Jadranu; Bucarelli, Micheletta, Monzali, and Riccardi, Italy and Tito's Yugoslavia; Škorjanec, Osimska pogajanja; Pirjevec, Klabjan, and Bajc Osimska Meja.

18 Marković and Obadić, "A socialist developing country," 89-111.

19 Milikić, Između Evrope i Nesvrstanosti. 


\section{Benedetto Zaccaria}

20 Artisien and Holt, "Yugoslavia and the E.E.C. in the 1970s," 355-69. On tourism, see Grandits and Taylor, Yugoslavia's sunny side.

21 Rafael Biermann, "Back to the roots," 29-50; Radeljić, Europe and the collapse of Yugoslavia.

22 This chapter is mostly based on archival sources in the Archives of Yugoslavia (Arhiv Jugoslavije) in Belgrade related to the Federal Executive Council, Federal Secretariat for External Trade, Cabinet of the President of the Republic and the SKJ. It also benefits from archival sources in the Diplomatic Archives of the Republic of Serbia.

23 Zaccaria, The EEC's Yugoslav Policy, 33.

24 Marković and Obadić, "A socialist developing country," 91.

25 Rajak, Yugoslavia and the Soviet Union in the early Cold War.

26 Arhiv Jugoslavije (AJ), Kabinet Predsednika Republike (KPR), 837, III-b-2-a, Naši odnosi sa Savetom za Uzajamnu ekonomsku pomoć (SEV), April 1962, Beograd.

27 AJ, KPR, 837, III-b-2-a, "Referat i ratifikaciji Sporazuma izmedju Vlade SFRJ i SEV," 16 December 1964.

28 Obadić, "A troubled relationship," 329-48.

29 AJ, Fond 751, File 115, "Informacija o poseti predsednika SIVa SFRJ Mike Špiljaka Italiji," 18 January 1968.

30 AJ, A-CK SKJ, IX, 48/I - 392-426, Komisija za medjunarodne odnose i veze, Italija, K. 9, Report of meeting between Popović and Trabalza, 12 February 1968.

31 Jakovina, Treća Strana, 34.

32 Banac, "We Did Not Quarrel, We Did Not Curse," 173-96.

33 AJ, KPR, II-5-c-2/197, "Predlog zaključaka Saveznog izvršnog veća o nekim ekonomskim pitanjima u vezi sa dogadjajima u Čehoslovačkoj," 2 September 1968.

34 AJ, KPR, III-b-2-a, "Izvod iz izlaganja Aleksadra Griličkova na sednici SIVa," 5 December 1968.

35 Arhiv Ministarstva za inostrane poslove Republike Srbije, Belgrade (AMIP), PA, R, 1968, f 141: b 434938, Brisel, 27 September 1968.

36 AJ, Fond 751, File 234, "Efekti pojedinih varijanti za rešenje problema izvoza goveda, govedjeg mesa i kukuruza u pregovorima sa EEZ," Beograd, 2 October 1969.

37 AJ, "Efekti pojedinih varijanti za rešenje problema izvoza goveda, govedjeg mesa i kukuruza u pregovorima sa EEZ," Beograd, 2 October 1969.

38 Dyker, Yugoslavia, 63-5.

39 Zaccaria, "Yugoslavia, Italy."

40 AJ, Fond 751, File 277, Pov. 57/2-69, L. Cukala to P. Tomić [SSST], 22 December 1969.

41 AJ, Fond 751, File 340, "Savezna Privredna Komora, Sekretarijat za privredne odnose sa inostranstvom, broj. 1732, Poseta delegacije BDI," Beograd, 16 October 1969.

42 AJ, KPR, III-b-2-a, "Informacija o EEZ i saradnji Jugoslavije sa ovom multilateralnom organizacijom," Beograd, 5 October 1970.

43 AJ, KPR, III-b-2-a, "Informacija o diskusiji Saveznog izvršnog veća po pitanju sredjivanja naših odnosa sa EEZ i stava Francuske,” Beograd, 31 January 1969.

44 Obadić, "A troubled relationship," 329-48.

45 "Jugoslovenska delegacija otputovala na pregovore sa ZET," Borba, 14 October 1968, 1; "European Economic Community will negotiate with Yugoslavia," Export Journal 13 (1968): 1.

46 AJ, KPR, III-b-2-a, "Izveštaj o održanim razgovorima šefova delegacija SFRJ i EEZ," 17 November 1968.

47 Dyker, Yugoslavia, 76-7.

48 Cohen, "Partisans, professionals, and proletarians," 446-78; Mencinger, "Uneasy symbiosis," 118-44.

49 Singleton, Twentieth-century Yugoslavia, 273.

50 Zaccaria, "Yugoslavia, Italy," 6-9.

51 AJ, KPR, I-3-b/42, "Kabinet B. Šnuderla, Informacija o odnosima SFRJ-EEZ," 6 December 1972. 
52 Angela Romano, "Behind closed doors," 107-22; Kansikas, “Acknowledging economic realities," 311-28.

53 Ljubodrag Dimić, "Josip Broz Tito," 183-204.

54 See Chapter 2 by Angela Romano in this book.

55 See Pustaj, Ekonomski odnosi SFRJ.

56 AJ, A CK SKJ, Komisija za medjunarodne odnose i veze, Italija, IX, 48/I - 490-525, K. 12, Report of meeting between SKJ and Italian Communist Party, 3-4 February 1972, 28 February 1972.

57 Zaccaria, "Learning from Yugoslavia?," 213-35; Johanna Bockman, Markets in the name of socialism.

58 Zaccaria, "Blowing up the self-management bubble," 125-42.

59 On Mansholt's attention to the "third world," see Garavini, After empires, 141-52.

60 AJ, Fond 130, File 1304, Stenographic notes of the 104th meeting of the SIV, 16 November 1972.

61 AJ, KPR, I-3-b/42, "Beleška u vezi prijema S. Mansholta," 16 December 1972.

62 AJ, KPR, I-3-b/42, Report of meeting between Kardelj and Mansholt, 17 December 1972.

63 See the vast documentation on direct contacts between the SSST and Yugoslav enterprises in AJ, Fond 751, File 615 (1971).

64 Žiberna, Mijalković, Rajković, and Stojković, Evropska ekonomska.

65 See, for example, Zdenko Rajh, "Smisao i opasnosti Mansholtovog plana za reformu poljoprivrede EEZ," Medjunarodna Politika, 16 May 1972, 25-7; Ladjević, "O monetarnoj integraciji," 83-105; Mileta, "Ekonomski odnosi," 142-60.

66 Maja Kovačević, "Medjunarodi problem," 147-80.

67 Toma Granfil, "Jugoslavija i EEZ," Medjunarodna Politika, 4 January 1970, 1-3; Boris Šnuderl, "Razvoj ekonomskih odnosa Jugoslavije i EEZ," Medjunarodna Politika, 1 January 1973, 5-6; Božidar Frangeš, "Jugoslavija i regionalna suradnja razvijenih zemalja. Poslije potpisivanja Zajedničke izjave SFRJ-EEZ," Medjunarodna Politika, 16 December 1976, 9-10; Žarko Tomašević, "Sporazum o ekonomskoj saradnji Jugoslavije i Evropske ekonomske zajednice," Medjunarodna Politika, 16 March 1980, 6-9; Stojan Andov, "Jugoslavija i EEZ," Medjunarodna Politika, 1 December 1980, 1-4.

68 Adamović, Jugoslavija i Evropska Ekonomska Zajednica, 252.

69 AJ, KPR, III-b-2-a, Pov.br. 117/1/73, "Informacija o prvoj fazi pregovora izmedju SFRJ i EEZ za zaključene novog trgovinskog sporazuma," Beograd, 17 May 1973.

70 AJ, Fond 130, File 1301, Stenographic notes of the 68th meeting of the SIV, 8 June 1972.

71 AJ, Stenographic notes of the 68th meeting of the SIV, 8 June 1972.

72 Banac, "We Did Not Quarrel," 182-91.

73 AJ, Fond 751, File 1047, "Godišnji izveštaj o spoljnoj trgovini i politici razvoja Jugoslavije," 16 May 1974.

74 AJ, Fond 751, File 894, "Odeljenje za medjunarodne organizacije to Poslovno udruženje tekstilne konfekcije Jugoslavije,” Beograd, 20 July 1973.

75 Korošić, "Economic system and economic policy," 261-72.

76 Zaccaria, The EEC's Yugoslav Policy, 73-98.

77 The statistics are drawn from OECD (Organisation for Economic Co-operation and Development) Economic Surveys, Yugoslavia 1981, 58, accessed 27 December 2019, www.oecd-ilibrary.org/economics/oecd-economic-surveys-yugoslavia-1981_eco_ surveys-yucs-1981-en.

78 Kotkin, "The kiss of debt," 80-93. On the rise of the debt question in Eastern Europe, see in particular Chapter 3 by Pal Germuska, Chapter 4 by Aleksandra Komornicka and Chapter 5 by Maximilian Graf in this book.

79 Official Gazzette of the SFRY, No. 15/1977.

80 Čolanović, Commercial guide to the economic system of Yugoslavia, 91-100. 


\section{Benedetto Zaccaria}

81 AJ, Fond 751, File 1047, "Privredna Komora Jugoslavije, Sekretarijat za metalnu i elektroindustriju, Broj. 1931/3," Beograd, 3 January 1974; AJ, Fond 751, File 1047, Privredna Komora Jugoslavije, Sekretarijat za hemijsku i gumarsku industriju, Broj. 2013/12, 31 January 1974.

82 AJ, Fond 751, File 1119, SSST (V. Mijalković) to Republican Secretariat for Agriculture and Forests in Ljubljana, 6 August 1975.

83 AJ, Fond 751, File 1119, "Tovarna Dekorativnih Tkanin, Bezcarinski izvoz u Zapadnu Njemačku," 5 March 1975.

84 AJ, Fond 751, File 1119, "Produzeće za uvoz i izvoz tekstilnih sirovina i gotovih proizvoda," 7 July 1975.

85 AJ, Fond 751, File 1119, "Udruženje Jugoslovenskih Železara, Broj. 021/JLj-206," 8 February 1974.

86 AJ, Fond 751, File 1119, Udruženje Jugoslovenskih Železara, 014/RP-882, "Saradnja sa EEZ-om u oblasti crne metalurgije," 28 August 1974.

87 Vinski, "Dugoročna kretanja stanovništva," 112.

88 OECD Economic Surveys, Yugoslavia 1981, 58, accessed 27 December 2019, www. oecd-ilibrary.org/economics/oecd-economic-surveys-yugoslavia-1981_eco_surveysyucs-1981-en.

89 Zaccaria, "Yugoslavia, Italy," 13-16.

90 Ruzicic Kessler, "Regional cooperation in Europe," 91-110.

91 AJ, Fond 130, File 2040, Stenographic notes of the 207th meeting of the SIV, 13 March 1974.

92 AMIP, PA, R, 1975, f 187: b 45293, Report from Brussels on relations between EEC and CMEA; AMIP, PA, R, 1976, f 181: b 494114, Brussels Delegation to SSIP, 21 June 1976.

93 AMIP, PA, R, 1975, f 187: b 45293, Note by P. Miljević, Brussels, 31 January 1975.

94 AJ, Fond 751, File 776, N. Filipović (Federal Secretariat for Economy) to M. Hadžić, 21 February 1973.

95 AJ, Fond 130, File 2045, Stenographic notes of the 45th meeting of the SIV, 30 December 1974.

96 AJ, Stenographic notes of the 45th meeting of SIV, 30 December 1974.

97 AJ, Fond 130, File 2317, Stenographic notes of the 50th meeting of the SIV, 30 January 1975.

98 AJ, Stenographic notes of the 50th meeting of the SIV, 30 January 1975.

99 AJ, Fond 751, File 894, Report of meeting with Luca Rosania, Vice-President of the EIB, 9 November 1973.

100 AJ, Fond 751, File 894, Note by the Cabinet of Boris Šnuderl, 19 November 1973.

101 AMIP, PA, R, 1975, f 188: b 436810, Report from Brussels Delegation, 26 July 1975. The EEC-Yugoslavia Mixed Commission was established in the 1970 trade agreement.

102 See "Pismo Borisa Šnuderla Sergeju Kraigherju, Ljubljana, junij 1974 - Doc. 80," VIRI 23 (2006): 241-2.

103 AJ, Fond 130, File 2321, Stenographic notes of the 207th meeting of the SIV, 23 October 1975.

104 AJ, Stenographic notes of the 207th meeting of the SIV, 23 October 1975.

105 AJ, KPR, III-b-2-a, Report on EIB mission, 15 February 1977.

106 AJ, Fond 130, File 2322, Stenographic notes of the 111th meeting of the SIV, 3 December 1975.

107 AJ, Stenographic notes of the 111th meeting of the SIV, 3 December 1975.

108 AJ, Stenographic notes of the 111th meeting of the SIV, 3 December 1975.

109 AJ, Fond 130, File 2916, Stenographic notes of the 209th meeting of the SIV, 23 January 1976.

110 AJ, Stenographic notes of the 209th meeting of the SIV, 23 January 1976. 
111 AJ, Stenographic notes of the 209th meeting of the SIV, 23 January 1976.

112 AJ, KPR, I-3-b/50, Report from SSIP, Pov. Br. 461732, 27 November 1976.

113 On the EEC's viewpoint on the 1976 Joint Declaration, see Zaccaria, The EEC's Yugoslav Policy, 99-128.

114 AJ, KPR, I-3-b/50, SSIP report on meeting with Van der Stoel, 28 November 1976.

115 Frangeš, "Jugoslavija i regionalna suradnja," 9-10.

116 On the European Community's perceptions of this change, see Zaccaria, The EEC's Yugoslav Policy, 139-43.

117 AJ, KPR, III-b-2-a, 72a, "Služba za spoljnopoltička pitanja, Beleška," 29 June 1978.

118 AJ, Fond 130, File 3768, Stenographic notes of the 6th meeting of the SIV, 29 June 1978.

119 AJ, KPR, I-3-b/55, Note on meeting between Tito and Emiel van Lennep, 14 December 1978 .

120 AJ, KPR, I-5-b/82-14, Report of Bakarić's mission in the Federal Republic of Germany, 16-18 January 1978.

121 AJ, Report of Bakarić's mission in the Federal Republic of Germany, 16-18 January 1978.

122 Vladimir Djuro Degan, "Institucionalni aspekti ekonomske suradnje," Medjunarodna Politika, 1 December 1976, $24-8$.

123 See the documentation in AJ, SKJ, 507, IX, S/q-325-329, K 23, D 324.

124 AJ, A CK SKJ, Komisija medjnunarodne odnose i veze, Italija, IX, 48, I - 526-571, K 13, "Etat actuel, possibilités et perspectives de la cooperation economique en Europe, Réunion des partis communists et ouvriers d'Europe," 19-20 April 1975.

125 AJ, Fond 130, File 4211, Stenographic notes of the 63th meeting of the SIV, 19 March 1979.

126 AJ, Fond 130, File 4212, Stenographic notes of the 79th meeting of the SIV, 10 May 1979.

127 Tvrtko Jakovina, "Sovjetska intervencija u Afganistanu," 295-320.

128 AJ, Fond 130, File 4627, Stenographic notes of the 185th meeting of the SIV,19 February 1980.

129 ADMIP, PA, R, 1980, f 240: b 410729, "Informacija o novom sporazum o ekonomskoj saradnji SFRJ-EEZ,” 3 March 1980.

130 Andov, "Jugoslavija i EEZ," 1-4.

131 Dyker, Yugoslavia, 120.

132 Dyker, Yugoslavia, 114-27.

133 See Zloch-Christy, Debt problems of Eastern Europe, 13-23.

134 On the global character of the 1980s debt crisis, see Bartel, "The power of omission," 200-20.

\section{Bibliography}

Adamović, Ljubiša S., ed. Jugoslavija i Evropska Ekonomska Zajednica. Beograd: Institut za Medjunarodnu Politiku i Privredu, 1988.

Artisien, Patrick F. R. and Stephen Holt. "Yugoslavia and the E.E.C. in the 1970s." Journal of Common Market Studies 18 (1980): 355-69.

Banac, Ivo. “'We Did Not Quarrel, We Did Not Curse': the price of Yugoslav independence after the Soviet intervention in Czechoslovakia." In The Balkans in the Cold War, edited by Svetozar Rajak, Evanthis Hatzivassiliou, Eirini Karamouzi and Konstantina E. Botsiu, 173-96. London: Palgrave Macmillan, 2017.

Bartel, Fritz. "The power of omission: the IMF and the democratic transitions in Poland and Hungary." In New perspectives on the end of the Cold War: unexpected transformations? edited by Bernhard Blumenau, Jussi M. Hanimäki and Barbara Zanchetta, 200-20. New York: Routledge, 2018. 
Bekić, Darko. Jugoslavija u Hladnom ratu. Odnosi s velikim silama 1949-1955. Zagreb: Globus, 1988.

Bianchini, Stefano. La diversità socialista in Jugoslavia: modernizzazione, autogestione e sviluppo democratico dal 1965 ad oggi. Trieste: Stampa Triestina, 1984.

Biermann, Rafael. "Back to the roots. The European Community and the dissolution of Yugoslavia - policies under the impact of global sea-change." Journal of European Integration History 10 (2004): 29-50.

Bockman, Johanna. Markets in the name of socialism: the left-wing origins of neoliberalism. Stanford: Stanford University Press, 2011.

Bucarelli, Massimo, Luca Micheletta, Luciano Monzali and Luca Riccardi, eds. Italy and Tito's Yugoslavia in the age of international détente. Brussels: Peter Lang, 2016.

Calic, Marie-Janine. "The beginning of the end: the 1970s as a historical turning point in Yugoslavia." In The crisis of socialist modernity: the Soviet Union and Yugoslavia in the 1970s, edited by Marie-Janine Calic, Dietmar Neutatz and Julia Obertreis, 66-86. Göttingen: Vandenhoeck \& Ruprecht, 2011.

Cohen, Lenard J. "Partisans, professionals, and proletarians: elite change in Yugoslavia, 1952-78." Canadian Slavonic Papers 21 (1979): 446-78.

Članović, Branko. Commercial guide to the economic system of Yugoslavia. Belgrade: YugoslaviaPublic, 1978.

Dimić, Ljubodrag. “Josip Broz Tito i 'Jugoslovenski pogled na Evropu'.” In Jugoslavija u Hladnom Ratu, edited by Aleksandar Životić, 183-204. Institut za noviji istoriju Srbije: Beograd, 2010.

Dragišić, Petar. "Jugoslovenski pogledi na evropsku ekonomsku zajednicu 1957-1973." Istorija 20. veka 36 (2018): 147-60.

Dyker, David A. Yugoslavia: socialism, development and debt. London: Routledge, 1990.

Garavini, Giuliano. After empires: European integration, decolonization, and the challenge from the global South 1957-1986. Oxford: Oxford University Press, 2012.

Grandits, Hannes and Karin Taylor, eds. Yugoslavia's sunny side: a history of tourism in socialism (1950s-1980s). Budapest: Central European University Press, 2010.

Heuser, Beatrice. Western 'containment' policies in the Cold War: the Yugoslav case, 1948-1953. London: Routledge, 1989.

Jakovina, Tvrtko. "Sovjetska intervencija u Afganistanu 1979. i Titova smrt." Historijski zbornik 60 (2007): 295-320.

Jakovina, Tvrtko. Treća Strana Hladnog Rata. Zaprešić: Fraktura, 2011.

Kansikas, Suvi. "Acknowledging economic realities. The CMEA policy change vis-à-vis the European Community, 1970-3." European Review of History 21 (2014): 311-28.

Korošić, Marijan. "Economic system and economic policy." In Essays on the political economy of Yugoslavia, edited by Rikard Lang, George Macesich and Dragomir Vojnić, 261-72. Zagreb: Informator, 1982.

Kosanović, Milan. "Brandt and Tito: between Ostpolitik and nonalignment." In Ostpolitik, 1969-1974: European and global responses, edited by Carole Fink and Bernd Schäfer, 232-43. Cambridge: Cambridge University Press, 2009.

Kotkin, Stephen. "The kiss of debt. The East bloc goes borrowing." In The shock of the global: the 1970s in perspective, edited by Niall Ferguson, Charles S. Maier, Erez Manela and Daniel J. Sargent, 80-93. Cambridge, MA: Belknap Press of Harvard University Press, 2010.

Kovačević, Maja. "Medjunarodi problemi i izučavanje procesa evropske integracije od osnivanja zajednica do Jedinstvenog evropskog akta." Medjunarodni problemi 70 (2018): 147-80. 
Kramer, Mark. "Stalin, the split with Yugoslavia, and Soviet-East European efforts to reassert control, 1948-53." In The Balkans in the Cold War, edited by Svetozar Rajak, Evanthis Hatzivassiliou, Eirini Karamouzi and Konstantina E. Botsiu, 29-63. London: Palgrave Macmillan, 2017.

Ladjević, Djordje. “O monetarnoj integraciji u Evropskoj Ekonomskoj Zajednici.” Medjunarodni problemi 25 (1973): 83-105.

Lampe, John R., Russell O. Prickett and Ljubiša S. Adamović. Yugoslav-American economic relations since World War II. Durham: Duke University Press, 1990.

Lees, Lorraine M. Keeping Tito afloat: The United States, Yugoslavia and the Cold War. University Park: Pennsylvania State University Press, 1997.

Marković, Andrej and Ivan Obadić. "A socialist developing country in a Western capitalist club: Yugoslavia and the OEEC/OECD, 1955-1980." In The OECD and the International Political Economy Since 1948, edited by Matthieu Leimgruber and Matthias Schmelzer, 89-111. London: Palgrave Macmillan, 2017.

Mencinger, Jože. "Uneasy symbiosis of a market economy and democratic centralism: emergence and disappearance of market socialism in Yugoslavia." In Equality, participation, transition - essays in honour of Branko Horvat, edited by Vojmir Franičević and Milica Uvalić, 118-44. London: Palgrave Macmillan, 2000.

Mileta, Vlatko. "Ekonomski odnosi izmedju država članica evropske ekonomske zajednice od osnivanja do danas." Politička Misao 11 (1974): 142-60.

Milikić, Ratomir. Između Evrope i Nesvrstanosti. Jugoslavija i Savet Evrope 1960-1980. Beograd: Institut za savremenu istoriju, 2017.

Mišić, Saša. Pomirenje na Jadranu. Jugoslavija i Italija na putu ka Osimskim sporazumima iz 1975. Beograd: Univerzitet u Beogradu, Fakultet političkih nauka, 2018.

Obadić, Ivan. "A troubled relationship: Yugoslavia and the European Economic Community in détente." European Review of History 21 (2014): 329-48.

Obadić, Ivan. In pursuit of stability: Yugoslavia and Western European economic integration, 1948-1970. PhD diss., European University Institute, 2017.

Perović, Jeronim. “The Tito-Stalin split: a reassessment in light of new evidence." Journal of Cold War Studies 9 (2007): 32-63.

Pirjevec, Jože, Borut Klabjan and Gorazd Bajc, eds. Osimska Meja. Jugoslovanskoitalijanska pogajanja in razmejitev leta 1975. Koper: Založba Annales, 2006.

Pustaj, Marko. Ekonomski odnosi SFRJ i nesvrstanih zemalja Afrike 1973-1981. Master's diss., University of Zagreb, 2016.

Radeljić, Branislav. Europe and the collapse of Yugoslavia: the role of non-state actors and European diplomacy. London: I. B. Tauris, 2012.

Rajak, Svetozar. Yugoslavia and the Soviet Union in the early Cold War: reconciliation, comradeship, confrontation, 1953-1957. London: Routledge, 2010.

Rajak, Svetozar. "From regional role to global undertakings: Yugoslavia in the early Cold War." In The Balkans in the Cold War, edited by Svetozar Rajak, Evanthis Hatzivassiliou, Eirini Karamouzi and Konstantina E. Botsiu, 65-86. London: Palgrave Macmillan, 2017.

Ramet, Sabrina P. The three Yugoslavias: state building and legitimation, 1918-2005. Washington, DC: Woodrow Wilson Center Press, 2006.

Romano, Angela. "Behind closed doors. Contacts between EEC and CMEA in the early 70s." In The Helsinki Process: a historical reappraisal, edited by Carla Meneguzzi Rostagni, 107-22. Padova: Casa Editrice Dott. Antonio Milani, 2005.

Ruzicic Kessler, Karlo. "Regional cooperation in Europe: Austria, Italy, Yugoslavia and the ‘Alps-Adriatic' region.” Europske studije - European Studies 2 (2015): 91-110. 


\section{Benedetto Zaccaria}

Ruzicic Kessler, Karlo and Petar Dragišić. "Zwischen Chance und Bedrohung: Die jugoslawischen Kommunisten und die westeuropäische Integration.” In Kommunismus und Europa. Europapolitik und vorstellung kommunistischer Parteien im Kalten Krieg, edited by Franscesco di Palma and Wolfgang Mueller, 138-56. Paderborn: Ferdinand Schöningh, 2016.

Singleton, Fred. Twentieth-century Yugoslavia. London: Macmillan Press, 1976.

Škorjanec, Viljenka. Osimska pogajanja. Koper: Založba Annales, 2007.

Unkovski-Korica, Vladimir. The economic struggle for power in Tito's Yugoslavia: from World War II to non-alignment. New York: I.B. Tauris, 2016.

Uvalić, Milica. Investment and property rights in Yugoslavia: the long transition to a market economy. Cambridge: Cambridge University Press, 1992.

Vinski, Ivo. "Dugoročna kretanja stanovništva i društvenog proizvoda Jugoslavije." In Aktuelni problemi privrednih kretanja i ekonomske politike Jugoslavije, edited by Dragomir Vojnić, 111-17. Zagreb: Informator, 1974.

Woodward, Susan L. Socialist unemployment: the political economy of Yugoslavia, 19451990. Princeton: Princeton University Press, 1995.

Zaccaria, Benedetto. The EEC's Yugoslav Policy in Cold War Europe, 1968-1980. London: Palgrave Macmillan, 2016.

Zaccaria, Benedetto. La strada per Osimo. Italia e Jugoslavia allo specchio (1968-1975). Milano: FrancoAngeli, 2018.

Zaccaria, Benedetto. "Learning from Yugoslavia? Western Europe and the myth of selfmanagement (1968-1975)." In Planning in Cold War Europe: competition, cooperation, circulations (1950s-1970s), edited by Sandrine Kott, Michel Christian and Ondrej Matejka, 213-35. Berlin: De Gruyter, 2018.

Zaccaria, Benedetto. "Blowing up the self-management bubble: Yugoslav propaganda and Italian reception in the early 1970s." Acta Histriae 27 (2019): 125-42.

Zaccaria, Benedetto. "Yugoslavia, Italy and European integration: was Osimo 1975 a Pyrrhic victory?" Cold War History (2019): 1-18. Accessed 26 December 2019. https://doi. org/10.1080/14682745.2019.1657094.

Žiberna, Milica, Vera Mijalković, Blagoje Rajković and Djordje Stojković. Evropska ekonomska zajednica i položaj Jugoslavije. Beograd: Privredni pregled, 1969.

Zloch-Christy, Iliana. Debt problems of Eastern Europe. Cambridge: Cambridge University Press, 1987. 